\title{
Antibacterial action of red and green propolis extract in infected root canal
}

Mônica Misaé Endo ${ }^{\text {, }}$ Cyntia R. A. Estrela ${ }^{b}$, Ana Helena G. Alencar ${ }^{c}$, Daniel Almeida Decurcioc ${ }^{c}$, Júlio Almeida Silva ${ }^{\mathrm{C}}$, Carlos Estrela ${ }^{\mathrm{C}}$

\begin{abstract}
OBJECTIVE: This study investigated the antibacterial action of $30 \%$ red propolis, $40 \%$ green propolis and $2.5 \%$ sodium hypochlorite with irrigation protocols in infected root canals.

METHODS: During 60 days, twenty-four root canals were inoculated with $E$. faecalis. In all experimental groups were performed root canal preparation and two irrigation protocols - passive ultrasonic irrigation and conventional irrigation. In the groups 1, 3, 5 and 7 it were made root canal preparation associated to conventional irrigation with $30 \%$ propolis, $40 \%$ propolis, $2.5 \%$ sodium hypochlorite and distilled water, respectively. In groups 2, 4, 6 and 8 it was made root canal preparation associated with passive ultrasonic irrigation with the solutions described above. The groups 9 and 10 were the controls (negative and positive). Samples of the root canals were collected and immersed in $7 \mathrm{~mL}$ of $\mathrm{BHI}$, for 48 hours, at $37^{\circ} \mathrm{C}$. Bacterial growth was analyzed by turbidity of the culture medium.

RESULTS: Antibacterial action was observed of $30 \%$ red propolis and $2.5 \%$ sodium hypochlorite when used passive ultrasonic irrigation and conventional irrigation after 20 minutes, but in 72 hours it was not effective.

CONCLUSION: The irrigating agents and protocols were not effective to eliminate the microorganisms of the infected root canals. Clinical Significance: Propolis presents potential for clinical application due to its antimicrobial, anti-inflammatory, antioxidant and low toxicity properties.
\end{abstract}

Key words: Endodontic; Propolis; Sodium hypochlorite

\section{Ação antimicrobiana do extrato de própolis vermelho e verde em canais radiculares infectados}

\section{RESUMO}

OBJETIVO: Investigar a ação antibacteriana do própolis vermelhos 30\%, do própolis verde $40 \%$ e do hipoclorito de sódio 2,5\% com protocolos de irrigação em canais radiculares infectados.

MÉTODOS: Durante 60 dias, vinte e quatro canais radiculares foram inoculados com $E$. faecalis. Em todos os grupos experimentais foi realizado o preparo do canal radicular e dois protocolos de irrigação - irrigação ultra-sônica passiva e irrigação convencional. Nos grupos 1, 3, 5 e 7 foi feito o preparo do canal radicular associado à irrigação convencional com própolis 30\%, própolis 40\%, hipoclorito de sódio 2,5\% e água destilada, respectivamente. Nos grupos 2, 4, 6 e 8 foi feito o preparo do canal radicular associado à irrigação ultra-sônica passiva com as soluções descritas acima. Os grupos 9 e 10 foram os controles (negativos e positivos). Amostras dos canais radiculares foram coletadas e imersas em $7 \mathrm{~mL}$ de BHI, durante 48 horas, a $37^{\circ} \mathrm{C}$. O crescimento bacteriano foi analisado por turvação do meio de cultura.

RESULTADOS: Ação antibacteriana foi observada com própolis vermelho 30\% e hipoclorito de sódio 2,5\% quando utilizado irrigação ultra-sônica passiva e irrigação convencional após 20 minutos, porém, após 72 horas as substâncias não foram efetivas.

CONCLUSÃO: Os agentes de irrigação e os protocolos não foram efetivos para eliminar os microorganismos dos canais radiculares infectados.

Palavras-chave: Endodontia; Própolis; Hipoclorito de sódio a Professor of Endodontics, School of Dentistry University of Anápolis UniEvangélica, Anápolis, $\mathrm{GO}$, Brazil

${ }^{b}$ Professor of Endodontics, School of Dentistry, University of Cuiabá, Cuiabá, MT, Brazil

${ }^{c}$ Professor of Endodontics, Department of Stomatologic Sciences, Federal University of Goiás, Goiânia, GO, Brazil 


\section{INTRODUCTION}

Bacteria constitute important etiologic agents for dental pulp and periapical tissues infection [1-3]. Bacterial growth is enhanced by complex anatomy of root canal system, inaccessible areas to endodontic instruments, which represent an ideal environment for bacterial biofilm structuring $[2,3]$. Bacterial biofilm is structured from microorganisms attachment on a solid surface embedded in an extracellular matrix, resistant to antimicrobial agents, what favors the maintenance of infection process and represents a special challenge for successful root canal treatment $[4,5]$.

Enterococcus faecalis is often isolated in teeth with failed root canal treated. The ability to invade the dentinal tubules, be resistant to antimicrobial agents and interfere with host defenses reveals its pathogenic role [6-8]. The use of antibacterial strategies that can promote the disruption of the biofilm is essential to the success of the endodontic therapy $[3,5]$. Sodium hypochlorite is extensively used in endodontics as irrigating solution due to its antimicrobial effect. The mechanism of action includes biosynthetic changes; destruction of phospholipids; chloramines formation which interfere in cell metabolism; oxidative action with enzymatic inactivation in bacteria and degradation of fatty acids and lipids ${ }^{9}$. However, extrusion of this irrigating solution can cause intense reactions in the periapical tissues [10].

Antimicrobial activity and biological responses of periapical tissues of irrigating solutions have stimulated studies looking for natural alternatives. In this regard, propolis has been investigated for presenting antimicrobial properties, anti-inflammatory, antioxidant, and others [11-24]. Because of its low toxicity, it has been studied as possible intracanal medication [11,12].

Maia Filho et al. [13] compared the effectiveness of $5 \%$ sodium hypochlorite, $2 \%$ chlorhexidine gel and propolis extract against $E$. faecalis by agar diffusion test. Propolis extract showed good antimicrobial activity. Koo et al. ${ }^{14}$ evaluated the antimicrobial activity method of $10 \%$ propolis extract and $10 \%$ arnica montana against fifteen microorganisms of the endodontic microbiota among which E. faecalis, by agar diffusion test. Propolis extract significantly inhibited the tested microorganisms with the largest inhibition zones for Actinomyces spp. In the analyzed propolis samples, from different regions, an important difference was found in total flavonoids after colorimetric analysis. The results indicated that the chemical composition of propolis, especially in relation to the total flavonoid content is dependent on a variety of factors. These flavonoids in propolis act on bacteria's membrane or cell wall, causing structural and functional damage ${ }^{19}$. Alencar et al. ${ }^{18}$ determining the minimum inhibitory concentration verified an antimicrobial activity of propolis against S. aureus and S. mutans.

Considering the potential of propolis as an antibacterial agent, the present study aims to evaluate the antibacterial activity of the alcoholic extract of $30 \%$ red propolis, $40 \%$ green propolis and $2.5 \%$ sodium hypochlorite, when subjected to passive ultrasonic irrigation in infected root canals.

\section{MATERIALS AND METHODS}

This study was approved by in Research Ethics Committee of the Federal University of Goiás. The study design was similar to that previously used ${ }^{8}$. A strain of $E$. faecalis was inoculated into $7 \mathrm{ml}$ of Brain Heart Infusion (BHI; Difco Laboratories, Detroit, MI, USA) and incubated for 24 hours at $37^{\circ} \mathrm{C}$. Bacterial cells were suspended in saline solution in order to achieve a concentration of about $3 \times 10^{8} \mathrm{ml}^{-1}$ cells adjusted to \#1 McFarland turbidity standard.

The sample included thirty single-rooted human teeth with intact cementum, extracted at the Dental Urgency Service of the School of Dentistry of the Federal University of Goiás, Brazil, for different reasons (periodontal, prosthetic or other). The teeth were stored in a bottle containing $0.2 \%$ thymol solution and subsequently immersed in 5\% sodium hypochlorite for 30 minutes to remove organic tissue. Periapical radiographs (Eastman Kodak. Comp., NY, USA) in buccolingual and proximal directions were taken to confirm presence of just one root canal and absence of anatomical variations. Teeth with obliteration of the radicular canal and root disruption were excluded.

After initial radiographs, the crowns were removed under continuous jet of air/water, with laminated drill Endo-Z (Maillefer, Ballaigues, Switzerland) at high speed. Radicular lengths were standardized at $16 \mathrm{~mm}$ (from the apex to the amelocementarium limit). The teeth were emptied to the apical limit with K-flex instrument \# 15 (Maillefer, Ballaigues, Switzerland). The anatomical diameter of the selected teeth was approximately 350-400 micrometers (diameter corresponding to K file-file No. 35/40) to penetrate and maintain just to the working limit. At the following radicular canals were prepared with BioRace system (FKG Dentaire, La Chaux-de Fonds, Switzerland) using the BR5 40/0.04 instrument. Conventional irrigation was performed with $3 \mathrm{~mL}$ of $2.5 \%$ sodium hypochlorite with a $5 \mathrm{ml}$ syringe and Endo Eze irrigation cannula (Ultradent Products Inc., South Jordan, UT, USA).

Subsequently, the canals were dried and filled with $17 \%$ EDTA (pH 7.2 - Biodynamics, Ibiporã, PR, Brazil) for 3 minutes to remove the smear layer and then autoclaved for 30 minutes at $120^{\circ} \mathrm{C}$.

\section{Experimental design}

A split platform was used during the inoculation period of the bacterial suspension. The coronal portion of the root canal of each tooth was connected to the bottom of a $1.5 \mathrm{~mL}$ polypropylene tube Eppendorf (Cral, São Paulo, SP, Brazil). Five milliliters of sterile BHI were mixed with $5 \mathrm{~mL}$ of the bacterial inoculum, and the experimental and positive control groups were inoculated with $E$. faecalis using sterile syringes with a sufficient volume to fill the root canal. This procedure was repeated every 72 hours, always using pure 
culture with 24 hours of preparation and set the standard \#1 McFarland.

During the 60 days of root canal infection, three teeth were left uncontaminated and incubated at $37^{\circ} \mathrm{C}$ as negative control and as positive control; three teeth were inoculated with E. faecalis and incubated at $37^{\circ} \mathrm{C}$. The negative control group was used to verify the sterility of the samples and the positive control group was used to check the bacterial viability during the experiment.

After the biofilm formation period, samples were collected from the root canals of all groups to check bacterial viability. The root canals were filled with sterile distilled water and three \#40 sterilized paper points (Tanari, Tanariman Industrial Ltda., Manacapuru, Amazonas, Brazil) were introduced into the radicular canal and maintained for 1 minute. The points were individually transported and immersed in $7 \mathrm{~mL}$ of BHI (Brain Heart Infusion; Difco Laboratories, Detroit, MI, USA) added with the neutralizers [Tween 80 and sodium thiosulfate (PA Art Laboratory, Campinas, Brazil)] at appropriate concentrations, followed by incubation at $37^{\circ} \mathrm{C}$ for 48 hours.

The teeth $(n=24)$ were randomly distributed into eight experimental groups $(n=3)$. In all the experimental groups were performed root canal preparation and two irrigation protocols - conventional irrigation and passive ultrasonic irrigation. In groups 1, 3, 5 and 7 was performed root canal preparation associated to conventional irrigation with the tested solutions: $30 \%$ red propolis alcoholic extract (Ilha do Porto Apiary, Alagoas, Al, Brazil, Natural Labor Laboratory), $40 \%$ green propolis alcoholic extract (Santo Antonio Apiary, São Paulo, SP, Brazil), 2.5\% sodium hypochlorite (Fitofarma, Goiânia, GO, Brazil) and sterilized distilled water. In groups 2, 4, 6 and 8 was performed root canal preparation associated to passive ultrasonic irrigation with the same solutions. Each group received the same irrigation solution volume $(27 \mathrm{~mL})$. The conventional irrigation process was carried out for groups 1, 3, 5 and 7 throughout the root canal preparation with a $5 \mathrm{~mL}$ syringe and Endo-Eze Irrigator Tip irrigation cannula (Ultradent Products Inc., South Jordan, UT USA) with $0.40 \mathrm{~mm}$ diameter positioned at $12 \mathrm{~mm}$. Group 9 was the positive control and group 10, the negative control (Table 1).

The groups were prepared with BioRaCe system extension (FKG Dentaire, Swiss Dental Products, La Chauxde-Fonds, Swiss) following sequence BR6 \#50.02, \#60.02 and BR7, each one used in only 5 root canals.

For groups 2, 4, 6 and 8 an ultrasonic stirring was performed during the last irrigation with ultrasonic device (EMS MW 200, Swiss), at 20\% power in accordance with the manufacturer's instructions. The ultrasonic tip (E1 irrisonic - Heise) was positioned in the radicular canal and activated for $30 \mathrm{sec}$, performing short shuttle movements, carefully not to touch the walls of the root canal and avoiding damaging it.

Root canals were irrigated with $3 \mathrm{~mL}$ of the tested solutions before radicular canal preparation, during and after instrumentation with instrument \#BR 50.02 and BR\#
60.02. Each group received the same volume of irrigating solution.

After the sanitization process of all experimental groups, each root canal was filled with $3 \mathrm{~mL}$ of $17 \%$ EDTA (pH 7.2Biodynamics, Ibiporã, PR, Brazil), which was kept under stirring with a hand file for 3 min to remove of smear layer. An additional irrigation with $5 \mathrm{~mL}$ of sterile distilled water was performed with a $5 \mathrm{~mL}$ syringe and Endo-Eze Irrigator Tip irrigation cannula (Ultradent Products Inc. South Jordan, UT, USA) to neutralize the effects of irrigating solutions in all experimental groups.

Samples from each tooth were taken from the root canal using three sterilized absorbent paper points \# 60 (Tanari, Tanariman Industry Ltda., Manacapuru, Amazonas, Brazil) which were introduced in each experimental group for $1 \mathrm{~min}$. Three absorbent paper points were individually transported and immersed in $7 \mathrm{~mL}$ of BHI (Brain Heart Infusion; Difco Laboratories, Detroit, MI, USA) added with neutralizers followed by incubation for $48 \mathrm{hs}$ at $37^{\circ} \mathrm{C}$. These procedures were repeated 1 minute after the conclusion of root canal preparation with the use of the tested solutions, after 20 minutes and after 72 hours of the conclusion of root canal preparation.

Bacterial growth was analyzed by turbidity of the culture medium through visual reading. After 48 hours an inoculum of $0.1 \mathrm{ml}$ from obtained medium was transferred to $7 \mathrm{~mL}$ of Letheen Brooth (Letheen Broth; Difco Laboratories, Detroit, MI, USA) and incubated for 48 hours at $37^{\circ} \mathrm{C}$.

Table 1. Experimental group's distribution.

\begin{tabular}{clc}
\hline Groups & Antibacterial strategies & $\begin{array}{c}\text { Samples } \\
(\mathbf{n}=\mathbf{3 0})\end{array}$ \\
\hline 1 & PCS+RPE 30\% (Conventional Irrigation) & 3 \\
2 & $\mathrm{PCS}+\mathrm{RPE} 30 \%$ (Passive Ultrassonic Irrigation) & 3 \\
3 & $\mathrm{PCS}+\mathrm{GPE} 40 \%$ (Conventional Irrigation ) & 3 \\
4 & $\mathrm{PCS}+\mathrm{GPE} 40 \%$ (Passive Ultrassonic Irrigation) & 3 \\
5 & $\mathrm{PCS}+\mathrm{NaOCl} 2,5 \%$ (Conventional Irrigation) & 3 \\
6 & $\mathrm{PCS}+\mathrm{NaOCl} 2,5 \%$ (Passive Ultrassonic Irrigation) & 3 \\
7 & $\mathrm{PCS}+\mathrm{H}_{2} \mathrm{O}$ distilled (Conventional Irrigation) & 3 \\
8 & $\mathrm{PCS}+\mathrm{H}_{2} \mathrm{O}$ distilled (Passive Ultrassonic Irrigation) & 3 \\
9 & Positive Control & 3 \\
10 & Negative Control & 3 \\
\hline
\end{tabular}

RCP: Root Canal Preparation; NaOCl: Sodium Hypochlorite 2.5\%; RPE: Red Propolis Extract; GPE: Green Propolis Extract.

\section{RESULTS}

The antibacterial action of the studied solutions is presented in Table 2. The results showed antibacterial effectiveness of $30 \%$ red propolis alcoholic extract and $2.5 \%$ sodium hypochlorite when using conventional or passive irrigation only after $20 \mathrm{~min}$. Irrigation protocols and the tested substances were not effective to eliminate $E$. faecalis from the root canals. 
Table 2. Antibacterial action of chemical substances in infected root canals.

\begin{tabular}{lccc}
\hline Groups/ Periods & 1 minute & 20 minutes & 72 hours \\
$\mathrm{RCP}+30 \% \mathrm{RPE}$ (Conventional Irrigation) & +++ & --- & +++ \\
$\mathrm{RCP}+30 \% \mathrm{RPE}$ (Passive Ultrassonic Irrigation) & +++ & --- & +++ \\
$\mathrm{RCP}+40 \% \mathrm{GPE}$ (Conventional Irrigation) & +++ & +++ & +++ \\
$\mathrm{RCP}+40 \% \mathrm{GPE}$ (Passive Ultrassonic Irrigation) & +++ & +++ & +++ \\
$\mathrm{RCP}+2.5 \% \mathrm{NaOCl}$ (Conventional Irrigation) & +++ & --- & +++ \\
$\mathrm{RCP}+2.5 \% \mathrm{NaOCl}$ (Passive Ultrassonic Irrigation) & +++ & --- & +++ \\
$\mathrm{RCP}+\mathrm{H}_{2} \mathrm{O}$ distilled (Conventional Irrigation) & +++ & +++ & +++ \\
$\mathrm{RCP}+\mathrm{H}_{2} \mathrm{O}$ distilled (Passive Ultrassonic Irrigation) & +++ & +++ & +++ \\
Positive Control & +++ & +++ & +++ \\
Negative Control & --- & --- & --- \\
\hline
\end{tabular}

RCP: Root canal preparation; RPE: Red Propolis Extract; GPE - Green Propolis Extract.

+++ : presence of bacteria; ---: absence of bacteria.

\section{DISCUSSION}

Several sanitization strategies for infected root canal aim to reduce the microorganisms, based on emptying and enlargement, associated with intracanal substances with antimicrobial activities, and finally the endodontic and coronal sealing. Root canal treatment can only be considered complete after the final tooth restoration [5,9].

Bacterial control remains challenging, and new auxiliary sanitization substances and processes has been under investigation. The alcoholic extracts of $30 \%$ red propolis, $40 \%$ green propolis and $2.5 \%$ sodium hypochlorite used as irrigating solutions in conventional and passive ultrasonic irrigation were not effective to decontaminate infected root canals.

Propolis has been studied due several properties, as antimicrobial, anti-inflammatory, antioxidant, and others [11-15, 17-33]. The chemical compounds found in propolis showed antimicrobial and tissue tolerance characteristics. The propolis used in this study presents flavonoids and phenolic compounds $[18,23]$. The $30 \%$ red propolis alcoholic extract has a chemical composition of $2.4 \%$ flavonoids and $13.2 \%$ phenolic compounds; while the of $40 \%$ green propolis alcoholic extract shows the composition of $3.52 \%$ flavonoids and $3.75 \%$ phenolic compounds. The antimicrobial property has been attributed much to the flavonoids [14,26], which are present in propolis with capacity to act on bacteria membrane or cell wall, dissolving the lipophilic part [27,28], causing structural and functional damage [19].

In the present study, the antibacterial action in the period of $20 \mathrm{~min}$ showed that conventional or ultrasonic irrigation using $30 \%$ red propolis alcoholic extract or $2.5 \%$ sodium hypochlorite was better than the $40 \%$ green propolis alcoholic extract. Al-Qathami and Al Madi [24] compared the antimicrobial activity of propolis and $2.5 \%$ sodium hypochlorite as canal irrigants. Irrigation with propolis showed no significant difference with $2.5 \%$ sodium hypochlorite. Ehsani et al. [29] compared the antimicrobial activity of Aloe Vera gel, $15 \%$ and $40 \%$ propolis alcoholic extract and $2 \%$ chlorhexidine. The $15 \%$ and $40 \%$ propolis extracts and Aloe Vera showed antibacterial effect on $E$. faecalis. Koo et al. [14] evaluated the antimicrobial activity of $10 \%$ propolis extract and $10 \%$ Arnica Montana on the endodontic microbiota, including E. faecalis. Propolis extract significantly inhibited the tested microorganisms. Gomes et al. [30] verified the antimicrobial efficacy of propolis in various concentrations $(5,10,15$ and $20 \%)$ on some microorganisms (C.albicans, S. mutans, S. aureus, E. faecalis, A. israelli) using agar diffusion test. All tested species were susceptible to propolis. Vargas et al. [31] evaluated an antibacterial action of 50\% propolis alcoholic extract. It demonstrated antibacterial activity by inhibiting the growth of Gram-positive in $92.6 \%$ and Gram-negative in $42.5 \%$. Propolis achieved a greater effectiveness against Gram-positive bacteria and limited against Gram-negative bacteria [32]. In the present study, it was observed an impregnation and oily darkened pigmentation in the experimental groups constituted by the $30 \%$ red propolis alcoholic extract and $40 \%$ green propolis alcoholic extract.

Several studies have considered sodium hypochlorite as the substance that agglutinates the largest number of characteristics for its use as irrigant in infected root canals $[4,5,8,9]$.

Bhardwaj et al. [34] reported that passive ultrasonic irrigation with $1 \%$ sodium hypochlorite was effective to completely remove $E$. faecalis biofilms compared to natural substances (Aloe Vera, Nona juice and propolis). Whereas, Harrison et al. [35] showed that $1 \%$ sodium hypochlorite with passive ultrasonic irrigation was effective, but not completely removed E. faecalis from infected radicular canals. Our results also showed that the irrigant solutions (30\% red propolis alcoholic extract, $40 \%$ green propolis alcoholic extract and $2.5 \%$ sodium hypochlorite) and the irrigation protocols (conventional and passive ultrasonic irrigation) were not able to kill $E$. faecallis in infected root canals. 
In the current context of endodontics, it must be considered all resources to achieve successful endodontic treatment. Sodium hypochlorite continues to express a wide range of indications as an irrigant for infected root canals.

\section{CONCLUSION}

The antibacterial action of $30 \%$ red propolis alcoholic extract and $2.5 \%$ sodium hypochlorite when used in conventional or passive ultrasonic irrigation was observed only after 20 minutes. The irrigating agents and protocols were not effective to eliminate the test microorganism from the infected root canal.

\section{REFERENCES}

1. Kakehashi S, Stanley HR, Fitzgerald RJ. The effects of surgical exposures of dental pulps in germ-free and conventional laboratory rats. Oral Surg Oral Med Oral Pathol. 1965;20(3):340-9. https://doi.org/10.1016/00304220(65)90166-0

2. Sundqvist G, Figdor D, Persson S, Sjögren U. Microbiologic analysis of teeth with failed endodontic treatment and the outcome of conservative re-treatment. Oral Surg Oral Med Oral Pathol Oral Radiol Endod. 1998;85(1):86-93. https://doi.org/10.1016/S1079-2104(98)90404-8

3. Nair PN, Henry S, Cano V, Vera J. Microbial status of apical root canal system of human mandibular first molars with primary apical periodontitis after "one-visit" endodontic treatment. Oral Surg Oral Med Oral Pathol Oral Radiol Endod. 2005;99(2):231-52. https://doi.org/10.1016/j.tripleo. 2004.10.005

4. Estrela C, Sydney GB, Figueiredo JAP, Estrela CRA. Antibacterial efficacy of intracanal medicaments on bacterial biofilm: a critical review. J Appl Oral Sci. 2009;17(1):1-7. https://doi.org/10.1590/S1678-77572009000100002

5. Estrela C, Holland R, Estrela CR, Alencar AH, Sousa-Neto MD, Pécora JD. Characterization of successful root canal treatment. Braz Dent J. 2014;25(1):3-11. https://doi.org/10.1590/0103-6440201302356

6. Sjögren U, Hägglund B, Sundqvist G, Wing K. Factors affecting the longterm results of endodontic treatment. J Endod. 1990;16:498-504. https:// doi.org/10.1016/S0099-2399(07)80180-4

7. Sedgley C, Nagel A, Dahlén G, Reit C, Molander A. Real-time quantitative polymerase chain reaction and culture analyses of Enterococcus faecalis in root canals. J Endod. 2006;32(3):173-77. https://doi.org/10.1016/j. joen.2005.10.037

8. Estrela C, Estrela CRA, Decurcio DA, Hollanda ACB, Silva JA. Antimicrobial efficacy of ozonated water, gaseous ozone, sodium hypochlorite and chlorhexidine in infected human root canals. Int Endod J. 2007;40(2): 85-93. https://doi.org/10.1111/j.1365-2591.2006.01185.x

9. Estrela C, Estrela CRA, Barbin EL, Spanó JCE, Marchesan MA, Pécora JD. Mechanism of action of sodium hypochlorite. Braz Dent J. 2002; 13(2):113-7. https://doi.org/10.1590/S0103-64402002000200007

10. Zhu WC, Gyamfi J, Niu LN, Schoeffel GJ, Liu SY, Santarcangelo F, Khan S, Tay, K.C, Pashey DH, Tay FR. Anatomy of sodium hypochlorite a conventional irrigation dents involving facial ecchymosis - A review. J Dent. 2013;4:935-48. https://doi.org/10.1016/j.jdent.2013.08.012

11. Arruda AO, Souza LG, Biz MT, Ramos IFAS, Figueiredo JAP, Mazzuoo C. Análise macroscópica e MEV da superfície do canal radicular após utilização do extrato de própolis a 0,25\% como irrigante. J Bras Endod. 2004;5(19):280-7

12. Ramos IFAS, Biz MT, Paulino N, Scremin A, Della Bona A, Barletta FB, Figueiredo JAP. Histopathological analysis of corticosteroid antibiotic preparation and propolis paste formulation as intracanal medication after pulpectomy: an in vivo study. J Appl Oral Sci. 2012; 20(1):50-6. https:// doi.org/10.1590/S1678-77572012000100010

13. Maia Filho EM, Maia CCR, Bastos ACSC, Novais TMG. Efeito antimicrobiano in vitro de diferentes medicações endodônticas e própolis sobre Enterococcus faecalis. Rev Gaucha Odontol. 2008;56(1):21-5.

14. Koo H, GOMES BPFA, Rosalen PL, Ambrosano GMB, Park YK, Cury JA. In vitro antimicrobial activity of propolis and Arnica montana against oral pathogens. Arc Oral Biol. 2000;45:141-8. https://doi.org/10.1016/S00039969(99)00117-X

15. Castro LM, Cury AJ, Rosalyn LP. Própolis do sudeste e nordeste do brasil: influência da sazonalidade na atividade antibacteriana e composição fenólica. Quim Nova. 2007;30(7):1512-6. https://doi.org/10.1590/S0100 40422007000700003

16. Bankova V. Chemical diversity of propolis and the problem of standardization. J Ethnopharmacol. 2005;100:114-7. https://doi.org/ 10.1016/j.jep.2005.05.004

17. Silva BB, Rosalen PL, Cury JA, Ikegaki M, Souza VC, Esteves A, Alencar SM: Chemical com-position and botanical origin of red propolis, a new type of Brazilian propolis. Evid Based Complement Alternat Med; 2008; 5:313-6. https://doi.org/10.1093/ecam/nem059

18. Alencar SM, Oldoni TLC, Castro ML, Cabral ISR, Costa-Neto CM, Cury JA, Rosalen PL, Ikegaki M. Chemical composition and biological activity of a new type of Brazilian propolis: Red propolis. J Ethno-pharmacolo. 2007;10:01-06. https://doi.org/10.1016/j.jep.2007.06.005

19. Scazzocchio F, D'Auria FD, Alessandrini D, Pantanella F. Multifactorial aspects of antimicrobial activity of propolis. Microbiol Res. 2005;4:327-33.

20. Van Der Sluis LWM, Versluis M, Wu MK, Wesselink PR. Passive ultrasonic irrigation of the root canal: a review of the literature. Int Endod J. 2007; 40:415-26. https://doi.org/10.1111/j.1365-2591.2007.01243.x

21. Bhuva B, Patel S, Wilson R, Niazi S, Beighton D, Mannocci F. The effectiveness of passive ultrasonic irrigation on intraradicular Enterococcus faecalis biofilms in extracted single-rooted human teeth. J Endod 2010;43:241-50. https://doi.org/10.1111/j.1365-2591.2009.01672.x

22. Batista LLV, Campesatto EA, Assis MLB, Barbosa APF, Girillo LAM, Dornelas CB. Comparative study of topical green and red propolis in wound repair in mice. Rev Col Bras Cirurg. 2012;39(6):515-20. https:// doi.org/10.1590/S0100-69912012000600012

23. Duarte S, Rosalen PL, Hayacibara MF et al. The influence of a novel propolis on biofilms of Streptococcus mutans and caries development in rats. Arch Oral Biol. 2006;51:15-22. https://doi.org/10.1016/j. archoralbio.2005.06.002

24. Al-QathamiH, Al-Madi BDS. Comparison of sodium hypochlorite, propolis and salineas root canal irrigants: A pilot study. Saudi Dent J. 2003; 15(2):100-3

25. Valera MC, Rosa JA, Maekawa LE. Action of propolis and medications against Escherichia coli and endotoxin in root canals. Oral Surg Oral Med Oral Pathol Oral Radiol Endod. 2010;110:70-4. https://doi.org/10.1016/j. tripleo.2010.01.029

26. Viuda-Martos M, Ruiz-Navajas Y, Fernandez-Lopez J, Pérez-Álvarez JA Functional Properties of Honey, Propolis, and Royal Jelly. J Food Sci. 2008;73(9):117-124. https://doi.org/10.1111/j.1750-3841.2008.00966.x

27. Cowan MM. Plant products as antimicrobial agents. Clin Microbiol Rev. 1999; 12:564-82.

28. Koru O, Toksoy F, Acikel CH, Tunca YM, Baysallar M, Uskudar Guclu A, Akca E, OzkokTuylu A, Sorkun K, Tanyuksel M, Salih B. In vitro antimicrobial activity of propolis samples from different geographical origins against certain oral pathogens. Anaerobe. 2007;13:140-5. https:// doi.org/10.1016/j.anaerobe.2007.02.001

29. Ehsani M, Marashi MA, Zabihi E, Issazadeh M, Khafri S. A Comparison between Anti-bacterial Activity of Propolis and Aloe vera on Enterococcus faecalis (an in vitro study). Summer 2013;2(7)1-8.

30. Gomes RT, Teixeira KIR, Cortés ME, Santos RV. Antimicrobial activity of a propolis adhesive formulation on different oral pathogens. Braz J Oral Sci. 2007;6(22):1387-91

31. Vargas AC, Loguercio AP, Witt NM, Costa MM, Silva MS, Viana LR. Atividade antimicrobiana "in vitro" de extrato alcóolico de própolis. Cien Rur. 2004;34(1):159-63. https://doi.org/10.1590/S0103-84782004000100024

32. Marcucci MC, Ferreres F, García-Viguera, Bankova VS, De Castro SL, Valente PHN, Dantas AP, Paulino N. Phenolic compounds from Brazilian propolis with pharmacological activities. J Ethnopharmacol. 2001;74: 105-12. https://doi.org/10.1016/S0378-8741(00)00326-3

33. Só MVR, Wagner MH, Rosa RA, Telles L, Colpani F, Henz S, Magro ML. Atividade antimicrobiana in vitro de uma suspensão de própolis frente ao Enterococcus faecalis. Rev Gaúcha Odontol. 2011;16(3):277-81.

34. Bhardwaj A, Velmurugan N, Sumitha Ballal S. Efficacy of passive ultrasonic irrigation with natural irrigants (Morinda citrifolia juice, Aloe Vera and Propolis) in comparison with $1 \%$ sodium hypochlorite for removal of $E$. faecalis biofilm: An in vitro study. Indian J Dent. 2012;24(1):35-41. https:// doi.org/10.4103/0970-9290.114938

35. Harrison AJ, Chivatxaranukul P, Parashos $\mathrm{P}$, Messer $\mathrm{HH}$. The effect of ultrasonically activated irrigation on reduction of Enterococcus faecalis in experimentally infected root canals. Int Endod J. 2010,43:968-77. https:// doi.org/10.1111/j.1365-2591.2010.01715.x 